\title{
THE EFFECT OF GOVERNMENT SIZE ON ECONOMIC GROWTH: EVIDENCE FROM GROSS STATE PRODUCT DATA
}

\author{
Garey Durden and Barry Elledge*
}

\begin{abstract}
Using newly released data from the Bureau of Economic Analysis, this paper provides empirical estimates of the effect of government employment on gross state product. Cross-sectional data from 1982 are combined with a simple growth model to show that higher levels of government employment generally have a positive and significant effect on gross state product, with state and local employment levels having apparently greater influence. A first-differences variant of the model supports the cross-sectional findings. However, the positive influence of absolute government size may be offset by a negative relationship between GSP growth and the relative size of government.
\end{abstract}

\section{INTRODUCTION}

Several recent studies have attempted to measure the impact of government size on national economic growth. Most of these (Rubinson 1977; Landau 1983, 1986; Ram 1986; Singh 1992) have used either cross-sectional and/or time series data from non-U.S. countries. In a 1988 exception, Grossman used aggregated U.S. time series data and GNP for the years 1929-82. Peden and Bradley (1989), also using U.S. time series data, investigated the linkages between govermment size, productivity, and economic growth for the postwar years. The results from these studies are briefly discussed later.

In this paper, we shift the focus to individual states, examining the effects of government size on levels of gross state product (GSP). Two methodologies are employed: the first involves deriving cross-sectional estimates for the 50 states using 1982 data; the second uses the first-differences technique to determine the impact of changes in government size on changes in GSP between 1972 and $1982 .^{1}$

The paper is organized as follows: A discussion of the positive and negative effects that government size may have on economic growth is presented in Section II. In Section III, we discuss the existing literature, and in Section IV, develop the models for the cross-sectional and first-differences estimations and discuss the data sources. In Section V, the empirical results are presented with concluding remarks presented in Section VI.

\footnotetext{
*The authors are Professors of Economics, Appalachian State University, Boone, North Carolina. The authors are grateful for the comments of the journal's reviewers and editors.
} 


\section{POSITIVE AND NEGATIVE EFFECTS OF GOVERNMENT SIZE}

Economic theory does not provide an unambiguous prediction of how government size affects economic growth; rather, the theory recognizes that government has both positive and negative influences with no clear prediction of the net effect. Government's role in providing law and justice, as well as public goods such as defense, dates to Pigou and is well known. Government investments in education and health care are thought to have provided great returns. Corrections of market failures that exist in the presence of externalities and monopoly are widely recognized as beneficial and within the desirable scope of government.

Grossman (1988) goes beyond most others in detailing the positive (and negative) aspects of government size and impact. He suggests that government employment may substitute for unemployment or directly counter the negative effects of discrimination on employment and income, a conclusion supported by other studies. Government may provide an example for others to follow in promoting equal opportunities for minorities in the workplace and in access to human capital enhancing training and education.

On the darker side, govemment is inefficient since it always occupies a position of monopoly. If we assume that government agents are driven by the self-interest principle, then interest groups can influence policy to the detriment of the public at large. Several early works provide bases for compelling arguments that increases in government size will slow the engine of private economic growth. Tullock's (1959) study of the effects of logrolling and Buchanan and Tullock's (1962) similar conclusions underscore the inefficiency with which representative government must necessarily operate. Niskanen (1971) demonstrates how perverse efficiency incentives among bureaucrats lead to the general goal of increasing budget and bureaucracy sizes beyond optimal limits as compared to the more efficient result that would occur in private markets. Similarly, Olson (1982) suggests that, over time, representative democracy will give rise to greater and greater accumulations of interest groups, and the resulting rent-seeking activities will act to slow growth. ${ }^{2}$ According to Olson's hypothesis, interest groups will maximize by expending scarce resources to enhance their share of a given pie as opposed to enlarging the pie via competitive profit-seeking and other efficiencyincreasing measures. Although both strategies will enhance the well-being of interest group members, the former is clearly superior from a rational interest perspective since the expected benefits to interest groups are large relative to the costs. In addition to the waste inherent in rent-seeking activities, Grossman (1988) argues that the excess burden of taxation may increase more than proportionately as the rate increases. 


\section{THE LITERATURE}

To establish the relationship between government and overall growth, existing studies usually employ a relatively simple neoclassical growth model. Gross national product (GNP) or gross domestic product (GDP) is used as the dependent variable with labor, capital, various government measures, and often a human capital proxy as independent variables. The results have been mixed, so that no general conclusions are possible.

Using U.S. time series data, Grossman (1988) found a positive and significant relationship between government and economic output growth rates. However, a negative relative size variable (percent of total output accounted for by the government sector) seems to completely cancel the positive effects associated with absolute government size. Relying on cross-country comparisons that utilize cross-sectional and time series data from 115 nations, Ram concluded that, while some evidence of a negative relationship exists for some countries, the overwhelming indication is that "government size has a positive effect on economic performance and growth" $(1986,202)$. Landau (1983) used data from 95 countries to perform cross-sectional estimates of the determinants of GDP growth. While he carefully hedged his conclusions because of perceived weaknesses in both the theoretical choice of variables and the available test data, Landau suggests a negative relationship between "the share of government consumption expenditure in GDP and the rate of growth per capital (sic) GDP" $(1983,790)$. In a related study, Landau (1986) also looked at several measures of government spending in lesser developed countries and found that: consumption expenditure either had no impact or reduced growth, and expenditures on education and government capital development expenditures had little or no effect. Landau did find that overall government investment contributed weakly to economic growth, but that this contribution was offset almost exactly by the crowding out of private investment and the increased taxation needed to finance such investment. Peden and Bradley (1989) employed U.S. time series data to conclude that "a substantial slowdown in productivity and economic growth in the seventies and eighties cannot be ascribed to traditional factors. We have found one potential additional source: the dramatic growth in the scale of government" $(1989,243)$. Rubinson (1977) utilized a sizable cross-country sample and concluded that increases in government size promote economic growth.

The present study will not provide any definitive answers with respect to the influence of government on economic growth. Rather, it will provide one more piece of evidence that can be evaluated within the context of what has gone before. Eventually, when data and methodologies have been sufficiently standardized, a consensus may emerge. Alternatively, inherent differences between 
countries and even between states and regions within countries may be such that no generalizable relationship exists. Time and additional research will surely illuminate, if not eliminate, these concerns.

\section{THE METHODOLOGY AND DATA}

The ideal situation would be to estimate the effects of relevant variables on a comprehensive measure of state or national well-being. However, there is no such perfect and comprehensive measure with data adequate for analysis. Values for gross national or gross state product both understate (they exclude, for example, the opportunity cost of household services) and overstate economic welfare (the cleanup of pollution is added to output value with no consequent reduction caused by the negative pollution effects).

As previous authors have recognized, the best available measure of economic welfare is gross product value, and we use gross state product (GSP) as the independent variable in all regressions. These data were compiled under the auspices of the Department of Commerce, Bureau of Economic Analysis, and were taken from a 1988 Survey of Current Business paper by Renshaw, Trott, and Friedenberg. The regression equation is:

$$
\begin{aligned}
G S P & =a+a_{1} \text { LABOR }+a_{2} \text { CAPITAL }+a_{3} \text { HUMAN CAPITAL } \\
& +a_{4} \text { GOVERNMENT }+e_{\mathrm{i}}
\end{aligned}
$$

The stochastic error term is $e_{i}$, and independent variable proxies include: LABOR; the total employed labor force: CAPITAL; no exact value of capital by state currently exists, but a proxy variable-capital charges-is available from Renshaw, Trott, and Friedenberg (1988): HUMAN CAPITAL; the mean level of EDUCATION by state: GOVERNMENT; proxies for government include STATE, FEDERAL, and LOCAL government employment, the sum of these (TOTAL) and a RELATIVE variable that is total government employment as a percentage of total employment. As noted above, the capital proxy is from the same source as GSP, and the remaining proxies are from the County and City Data Book (1972 and 1982).

\section{REGRESSION RESULTS}

For cross-sectional tests, five versions of Equation (1) were estimated, using ordinary least squares. The results are presented in Table 1 . The equation was also 
TABLE 1

Regression Coefficients for Gross State Product for the 50 States, 1982 Data

\begin{tabular}{|c|c|c|c|c|c|}
\hline $\begin{array}{l}\text { Equation Estimate: } \\
\text { Variable }\end{array}$ & 1 & 2 & 3 & 4 & 5 \\
\hline Constant & -216568 & -153922 & -279539 & -211765 & -230090 \\
\hline LABOR & $\begin{array}{r}8.39 \\
(.0001)\end{array}$ & $\begin{array}{r}7.81 \\
(.0001)\end{array}$ & $\begin{array}{r}13.15 \\
(.0001)\end{array}$ & $\begin{array}{r}16.22 \\
(.0001)\end{array}$ & $\begin{array}{r}5.99 \\
(.0025)\end{array}$ \\
\hline CAPITAL & $\begin{array}{r}2.18 \\
(.0001)\end{array}$ & $\begin{array}{r}2.17 \\
(.0001)\end{array}$ & $\begin{array}{r}2.22 \\
(.0001)\end{array}$ & $\begin{array}{r}2.26 \\
(.0001)\end{array}$ & $\begin{array}{r}2.20 \\
(.0001)\end{array}$ \\
\hline EDUCATION & $\begin{array}{r}16946 \\
(.0001)\end{array}$ & $\begin{array}{r}12139 \\
(.0009)\end{array}$ & $\begin{array}{r}21890 \\
(.0001)\end{array}$ & $\begin{array}{r}16647 \\
(.0015)\end{array}$ & $\begin{array}{r}18884 \\
(.0001)\end{array}$ \\
\hline TOTAL GOVT EMP & $\begin{array}{r}61.30 \\
(.0001)\end{array}$ & & & & $\begin{array}{r}74.91 \\
(.0001)\end{array}$ \\
\hline LOCAL GOVT EMP & & $\begin{array}{l}113.29 \\
(.0001)\end{array}$ & & & \\
\hline STATE GOVT EMP & & & $\begin{array}{l}126.11 \\
(.0036)\end{array}$ & & \\
\hline FEDERAL GOVT EMP & & & & $\begin{array}{r}26.59 \\
(.2600)\end{array}$ & \\
\hline RELATIVE GOVT SIZE & & & & & $\begin{array}{l}-577.82 \\
(.0113)\end{array}$ \\
\hline Adjusted $\mathbf{R}^{2}$ & .995 & .996 & .993 & .992 & .996 \\
\hline
\end{tabular}

Significance values in parentheses with all results significant at 5 percent or better except for FEDERAL in Equation 4.

the basis for the first-differences estimations, which are presented and discussed in the text following the table.

The regression coefficients in column (1) show a positive and significant relationship between GSP and LABOR, CAPITAL charges, EDUCATION, and TOTAL (federal, state, and local) government employment. To test for different effects for type of govemment employment, we reestimated the equation three times, introducing LOCAL only, then STATE only, and finally FEDERAL only. Column (2) shows a positive and significant coefficient for LOCAL. Column (3) shows a positive and significant coefficient for STATE government employment. Column (4) shows a positive but insignificant coefficient for FEDERAL. The nongovernment coefficients are reasonably stable across all four estimations, and the adjusted $R^{2}$ values are uniformly high. It appears that local and state government employment contributes to higher levels of GSP; however, in these regressions, FEDERAL is shown to be insignificant.

The results of tests for the Grossman effect (measuring both positive and negative influences of government size) are presented in column (5). The positive 
sign on TOTAL GOVERMENT and the negative one on RELATIVE (government employment as a percentage of total employment) are consistent with Grossman's findings. We find both coefficients to be statistically significant, as did he.

The first-differences estimates for 1972-1982 yielded the following results:

$$
\begin{aligned}
& \text { GSP }=2418+7.43 \text { LABOR }+2.69 \text { CAPITAL }-8002.26 \text { EDUCATION } \\
& \begin{array}{lll}
(.0551) \quad(.0001) \quad(.0018) & 0
\end{array} \\
& +145.79 \text { TOTAL + 3193.91 RELATIVE } \quad \text { Adjusted } R^{2}=.971 \text {. } \\
& \text { (.0001) (.3782) }
\end{aligned}
$$

The changes in LABOR and CAPITAL were significant, TOTAL was positive and significant, while RELATIVE was positive and insignificant. An unexpected result was the change in sign for EDUCATION; the coefficient is also statistically significant. There is no obvious explanation for this result. The first differences used in this equation should lessen any multicollinearity problems and may be the most useful of the various models. ${ }^{3}$

While generalizations regarding the effect of government size on economic growth are far from settled, these findings contribute to the growing body of literature. Results generally suggest a positive relationship between GSP and government and a greater degree of importance to the size of state and local government as opposed to federal. The view that large government is a hinderance to economic growth is not confirmed by our findings, at least over the range of data used.

\section{CONCLUDING REMARKS}

Since theory provides no clear prediction of how government size may affect economic growth, researchers must rely heavily on empirical analyses. Not surprisingly, the results have been mixed. Grossman (1988), Ram (1986), and Rubinson (1977) found a generally positive relationship, while Landau (1983, 1986) and Peden and Bradley (1989) found that government size tends to retard overall growth.

This paper has used a simple growth model and newly released data for the 50 states to examine the impact of government employment on gross state product. The results generally support those from the Grossman, Ram, and Rubinson studies. We found positive and statistically significant relationships for most versions of the model including cross-sectional and first-differences estimations. 
State and local government growth may be more influential than the federal counterpart.

A drawback to existing studies-including this one-is that while the ultimate purpose is to measure the overall effect of government activity, including regulation, on a comprehensive measure of economic welfare, data limitations preclude this. While GSP is undoubtedly correlated with economic welfare, there are many aspects of our economic well-being not measured by simple measures of output value. All statistical results and conclusions must be interpreted with caution. Given the interest generated on this issue, especially among public choice scholars, these results, although incomplete, should be of interest.

\section{ENDNOTES}

1. We are gathering data for a time series analysis and hope to report the results in a future paper.

2. Since the notion of rent seeking was introduced into the literature by Tullock (1967) and formally named by Kruger (1974), a considerable, mostly theoretical, literature has evolved. See, for example, the summary by Tollison (1982) and the edited collections of Buchanan, Tollison, and Tullock (1980) and Rowley, Tollison, and Tullock (1988). More recently, a few empirical studies (Laband and Sophocleus 1988; Durden 1991; Courbois 1991) have begun to appear.

3. We recognize a possible multicollinearity problem with our data that may affect the lack of significance of some of the variables. This is likely a common problem in other studies as well and one we hope to address in further research.

\section{REFERENCES}

Buchanan, J., and G. Tullock. The Calculus of Consent. Ann Arbor: The University of Michigan Press, 1962.

Buchanan, J., R. Tollison, and G. Tullock, eds. Toward a Theory of the Rent-Seeking Society. College Station: Texas A\&M University Press, 1980.

Courbois, J. P. "The Effect of Predatory Rent-Seeking on a Household Saving and Portfolio Choices: A Cross-Section Analysis." Public Choice 70 (1991): 251-65.

Durden, G. C. "The Effect of Government Employment on Family Income Levels: Some Suggestive Empirical Evidence." Public Choice 67 (1991): 285-91. 
Grossman, J. "Government and Economic Growth: A Non-Linear Relationship." Public Choice 56 (1988): 193-200.

Kruger, A. O. "The Political Economy of the Rent-Seeking Society." American Economic Review 64 (1974): 291-303.

Laband, D. N., and J. P. Sophocleus. "The Social Cost of Rent-Seeking: First Estimates." Public Choice 58 (1988): 269-276.

Landau, D. N. "Government Expenditures and Economic Growth in the Less-Developed Countries: An Empirical Study for 1960-1980." Economic Development and Cultural Change (October 1986): 35-75. "Government Expenditure and Economic Growth: A Cross-Country Study." Southern Economic Journal 49 (1983): 783-92.

Niskanen, W. A. Bureaucracy and Representative Government. Chicago: Aldine Publishing Co, 1971.

Olson, M. The Rise and Decline of Nations: Economic Growth, Stagflation and Social Rigidities. New Haven: Yale University Press, 1982.

Peden, E. A., and M. J. Bradley. "Government Size, Productivity and Economic Growth: The Post-War Experience." Public Choice 61 (1989): 229-245.

Ram, R. "Government Size and Economic Growth: A New Framework and Some Evidence from Cross-Section and Time-Series Data." American Economic Review 76 (1986): 191-203.

Renshaw, V., E. A. Trott, and H. L. Friedenberg. "Gross State Product by Industry, 1963-1986." Survey of Current Business (May 1988): 30-46.

Rowley, C., R. Tollison, and G. Tullock, eds. The Political Economy of Rent Seeking. Boston: Kluwer Academic Press, 1988.

Rubinson, R. "Dependency, Government Revenue, and Economic Growth, 1955-70." Studies in Comparative International Development 12 (1977): 3-28.

Singh, R. D. "Government-Introduced Price Distortions and Growth: Evidence from Twenty-Nine Developing Countries." Public Choice 73 (1992): 83-99.

Tollison, R. D. "Rent-Seeking: A Survey." Kyklos 4 (1982): 575-602.

Tullock, G. "Problems of Majority Voting." Journal of Political Economy 67 (1959): 572-579.

. "The Welfare Costs of Tariffs, Monopolies, and Theft." Western Economic Journal (June 1967): 224-232.

U.S. Bureau of the Census. County and City Data Books, 1972; 1982. (A Statistical Supplement). Washington, D.C.: U.S. Government Printing Office, 1973 and 1983. 